Bangladesh J. Sci. Ind. Res. 42(4), 495-498, 2007

\title{
Extraction and Estimation of furfural from Decorative Plants Grown in Bangladesh
}

\author{
M.A.Sattar, A.K.Chakraborty, S.M.Al-Reza and Md.Shaharul Islam \\ Department of Applied Chemistry and Chemical Technology \\ Islamic University, Kushtia, Bangladesh
}

\begin{abstract}
An investigation on some decorative plants widely grown in Bangladesh has been carried out. The plants Mimusops elengi, Madhuca indica, Hiptage benghalensis and Polyalthia longifolia have been analyzed for their furfural contents by colorimetric spectrophotometry after hydrolysis in 13 percent $\mathrm{HCl}$ and extraction with $50 \%$ ethanol. The results revealed that the furfural concentration in these plants is in the range of 3.9-10.3 percent, indicating the potential of these plants as good source of pentosans and furfural. TLC and conventional chemical test further confirmed the presence of furfural in extracted solution.
\end{abstract}

Key words : Decorative plan, pentosans, furfural, TCL.

\section{Introduction}

Raw materials are an important factor for the industrial growth of a country. The proper utilization of indigenously available organic resources not only solves the disposal problem and ensures rich dividends to the farmer, but also can open up a reservoir of natural resources for meeting the various challenges now being faced in the development of new industries. The importance of agricultural and forestry waste in the national economy for the production of useful chemicals has been emphasized (Al-Showiman, 1998). Many forms of lignocellulosic biomass of agricultural and forest processing residues as well as soft wood and hard wood trees are largely available and remain underutilized. The hemicelluloses contained in these materials could be hydrolyzed with mineral acids to yield furfural, an important industrial chemical ( Carraseo, 1993).

Furfural finds various applications in rapidly developing industries as an intermediate chemical for the production of nylon, pyrrole, pyrrolidine, lysine, furfuryl and tetrahydrofurfuryl alcohol (Dunlop and Peters, 1953). Many furfural derivatives have been used as pharmaceuticals, fungicides and herbicides (Kirk-Othmer, 1966). Furfural is also the most commonly used sol- 
vent in petroleum refining industries and is in great demand for separating saturated compounds from unsaturated ones for the extraction of lubricating oils, gas oils and diesel fuels (Daous and Yorulmaz, 1989).

Recently many decorative plants of various genera have been planted on the streets of cities and government institutions throughout Bangladesh for beautification. Trimming of these plants seasonally may produce several tones of wastes and some of which are used as cattle feeds or other purposes, while the rest are considered as waste. These abundant agricultural wastes could be utilized for the production of useful chemical such as furfural. The pentosan content of these agricultural residues makes them suitable source of furfural production on a commercial scale. In view of the increasing trend of development and reliance on biomass as a source to meet the future demand for chemicals and fuels, the present work was undertaken to study the furfural content of some decorative plants grown in Bangladesh using $50 \%$ ethanol and $13 \%$ hydrochloric acid for its extraction (Ranganna, 1977). The furfural content was determined spectrophotometrically (Al-Showiman, 1998).

\section{Materials and Methods}

\section{Apparatus and reagents}

1. Spectrophotometer : Model-6051 UV/Visible (Jenway company, UK) with 10 mm cells.
2. $50 \%$ ethyl alcohol : $50 \mathrm{ml}$ absolute ethanol (E-Merck, Germany) diluted in 50 $\mathrm{ml}$ distilled water.

3. $13 \%$ Hydrochloric Acid : $35.2 \mathrm{ml} \mathrm{HCl}$ was taken from supplied 37\% $\mathrm{HCl}$ (Riedelde Haen, Germany) in $100 \mathrm{ml}$ volumetric flask.

4. Water : Double distilled water was used through out the study.

5. Aniline : Analar grade (E-Merck, India)

6. Furfural standard solution: Furfural standard solutions were prepared using 50\% ethanol as an internal solvent.

Samples of the decorative plants Mimusops elengi, Madhuca indica, Hiptage benghalensis and Polyalthia longifolia were collected from around the University Campus where they were grown. The leaves of all species were thoroughly washed with cold distilled water to remove any impurities and dried under diffused sunlight. The dried materials were then pulverized into powder with the help of a hammer. The furfural content was determined spectrometrically by measuring the intensity of absorbance at $530 \mathrm{~nm}$ using ethanol-hydrochloric acid-aniline reagent (Al-Showiman,1998).

\section{Standard solution}

The reagent grade furfural was first distilled to obtain a clear slight greenish-yellow liquid. $1 \mathrm{ml}$ of distilled furfural was taken in a 
$100 \mathrm{ml}$ volumetric flask and then made up to the mark with $50 \%$ ethanol as a solvent. Aliquots $(0,0.1,0.3,0.5,0.7,0.9 \mathrm{ml})$ of the standard furfural solution were separately taken in six different $25 \mathrm{ml}$ volumetric flasks and made up to the mark with 50\% ethanol. Then $1 \mathrm{ml} \mathrm{90 \%} \mathrm{aniline} \mathrm{and} 0.25 \mathrm{ml} \mathrm{37 \%}$ hydrochloric acid were added as a coloring agent. The mixtures were allowed to stand in dark for $15 \mathrm{~min}$ at room temperature to develop a red color. The intensity of the color was measured at $530 \mathrm{~nm}$ using the UV/Visible spectrophotometer.

\section{Sample preparation}

$2.5 \mathrm{~g}$ of each powdered sample was placed in a $100 \mathrm{ml}$ round-bottomed flask. To this 25 $\mathrm{ml}$ of $13 \% \mathrm{HCl}$ and $100 \mathrm{ml}$ of $50 \%$ ethanol were added and fitted with reflux condenser and guard tube. The contents were refluxed for three hours. The solution was cooled to room temperature. Then the contents were filtered using filter cloth. The clear solution was collected in a conical flask. The presence of furfural in the extracted solution was ascertained by conventional chemical test and TLC-technique.

\section{Colorimetric analysis}

The determination of furfural concentration of the plant samples was carried out spectrophotometrically by measuring the absorbance at $530 \mathrm{~nm}$ using ethanolhydrochloric acid-aniline method (AlShowiman,1998).

$5 \mathrm{ml}$ of the extracted solution was taken in a $25 \mathrm{ml}$ volumetric flask and made up to the

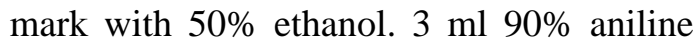
and $0.25 \mathrm{ml} 37 \%$ hydrochloric acid were then added. The mixture was allowed to stand for $15 \mathrm{~min}$ at room temperature in dark to develop a red color. The absorbance of the red color was measured at $530 \mathrm{~nm}$ using Colorimeter-6051 along with the absorbance of standard furfural solutions. The concentrations of furfural in the extracted samples were determined using the standard curve.

\section{Results and Discussion}

The results of the spectrophotometric determination of furfural content in the four species of decorative plants given in Table I are based on the ratio of the weight of furfural produced to the original solid weight ( $\mathrm{g} / \mathrm{g}$ ) of the species.

Table I. The furfural yield from some species of decorative plants grown in Bangladesh after hydrolysis in $13 \% \mathrm{HCl}$ concentration

\begin{tabular}{l|c|c}
\hline Name of the plants & Furfural (g/g) based on dry weight of plants & \% Furfural \\
\hline Mimusops elengi (Bokul) & 0.0103 & 10.3 \\
Madhuca indica (Mohua) & 0.078 & 7.8 \\
Hiptage benghalensis (Madhobilata) & 0.048 & 4.8 \\
Polyalthia longifolia (Debdaru) & 0.039 & 3.9 \\
\hline
\end{tabular}


The isolated furfural was characterized by its color with aniline-hydrochloric acid solution, which is considered as the method of choice. Because of the reproducibility of colorant formation from furfural and anilinehydrochloric acid. In this method, there is a good solubility of furfural in $50 \%$ ethanol; the decomposition mixture of sample substance and $\mathrm{HCl}$ is topped with a layer of $50 \%$ ethanol and direct measurement of the concentration of furfural was carried out in $50 \%$ ethanol at the end of the reaction time. It was observed that the color intensity decreases with time; so the time interval of 15 min after addition of coloring reagent till the observation was kept constant for measuring the concentration of furfural in all samples. The separated acid layer was tested using aniline-hydrochloric acid solution to check any traces of furfural and the result was found to be negative.

The calibration graph for the standard furfural sample was a plot of absorbance vs concentration and gave a linear relationship. The absorptivity calculated from the slope of the graph was $83.591 \mathrm{~L} \mathrm{~mol}^{-1} \mathrm{~cm}^{-1}$ at $530 \mathrm{~nm}$.

It can be observed from the results, summarized in Table I, that the furfural content in the leaves of different species of the decorative plants varies from one plant to another and the difference may be rationalized due to the changes in pentosan content as a result of soil, regional and seasonal conditions.

From the results it could be concluded that the biomass residues of these decorative plants could be considered as good sources for the pentosan content to be utilized possibly in future for the production of furfural, an important chemical in the development of modern industries for petroleum refining, vegetable oils, plastics, pharmaceuticals, cosmetic industries etc.

\section{References}

Al-Showiman, S.S. (1998) Extraction and estimation of furfural from decorative plants. $J$. Sci. \& Ind. Res., 57, 908.

Al-Showiman, S.S. (1998) Extraction and estimation of furfural from decorative plants. $J$. Sci. \& Ind. Res., 57 : 908.

Carraseo, F. (1993) Wood Fiber Science, $25: 91$.

Daous, M.A. and Yorulmaz, Y. (1989) Alternate Energy Sources, 1 : 815.

Dunlop, A.P. and Peters, F.N. (1953) The Furan, American Chemical Society Monograph Series, 273.

Kirk-Othmer, (1966) Encyclopedia of Chemical Technology, 2nd Ed., 10 : 243.

Ranganna, S. (1977) Manual of Analysis of Fruit and Vegetable Products (CFTRI Bangalore), 324.

Received : October, 27, 2005;

Accepted : September, 9, 2007 